\title{
Using Active Learning Spaces to Support Flipped Classroom
}

\author{
Rui $\mathrm{Li}^{1}$, Lei $\mathrm{Zhu}^{2}$, JT Singh ${ }^{3}$, Yongyi Mo ${ }^{4}$ \\ ${ }^{1}$ Distance Education Department, West Chester University of Pennsylvania, USA, \\ ${ }^{2}$ Department of Economics \& Finance, West Chester University of Pennsylvania, USA, \\ ${ }^{3}$ Educational Technology Department, West Chester University of Pennsylvania, USA, \\ ${ }^{4}$ College English Department, Beijing Jiaotong University, China.
}

\begin{abstract}
Flipped Classroom, an emerging type of blended instruction, has become a popular pedagogical approach in the recent years. Active learning classroom spaces have been implemented in many university campuses to facilitate student-centered, collaborative learning environment. The purpose of this study is to examine the effectiveness of a college level flipped classroom conducted in an active learning classroom space as compared to its traditional face-to-face counterpart. Two sections of a business course taught by the same instructor during one semester were selected for the study. The two sections had the exact same coverage and evaluation policy while one is a flipped class conducted in an active learning classroom space and the other is a traditional face-to-face class. We conducted both quantitative and qualitative analyses and our results reveal that there is no statistically significant difference of students' performance between the two classes. However, students reported a more positive learning experience in the flipped classroom setting.
\end{abstract}

Keywords: Active Learnig Spaces; Flipped Classroom; Active Learing; Student Engagement; Distance Education. 


\section{Introduction}

Distance education is one of the fastest growing trends in educational uses of technology. It continues to grow and the growth rate shows no sign of slowing down in the near future. According to the most recent Distance Education Enrollment Report, from Fall 2015 to Fall 2016, 31.6\% of all students in higher education are taking at least one distance education course (Seaman et al., 2018). There are more than 6 million students in the U.S. that are now enrolled in higher education distance education courses.

The quality of distance education has always been a concern. The Department of Education conducted a meta-analysis to review online learning studies (Means et al., 2010). The results showed that instruction combining online and face-to-face elements had a larger advantage relative to purely face-to-face instruction. The mean effect size in studies comparing blended with face-to-face instruction was $+0.35(p<.001)$. Blended instruction has become increasingly popular in higher education settings, offering students both the benefits of face-to-face instruction and the flexibility of online learning.

\subsection{Flipped Classroom}

Flipped Classroom, an emerging type of blended instruction, has become a popular class structure in the recent years. The term refers to a pedagogical model in which the lecture and homework elements of a course are reversed. Typically, the instructor provides prerecorded lectures for students to view at home before the class session. The videos might contain self-check quizzes which provide immediate feedback of the student's understanding of the course material. The students then bring their questions to the class and participate in the in-class discussions and activities led by the instructor.

A Flipped Classroom model gives students control of the prerecorded lectures so they can watch, rewind, and repeat as needed. It also allows instructors to devote more class time to application of the lectured content, hands-on activities, discussion and interaction. Additionally, this model allows institutions to strategically move some of the contact hours or seat-time that normally occurs in the classroom to an online setting, and ultimately frees up classroom space.

It has been documented that given enough blended courses, an institution can significantly increase capacity to serve additional students (Shea, 2007). This increased physical capacity makes higher education more accessible without additional investment in physical infrastructure. Furthermore, it reduces students' need to be on campus at a particular time. By putting the course lectures online, students can access the material anytime anywhere, which provides them with great flexibility. This is especially helpful for students with long commutes as they don't have to spend time commuting and parking. It can add up to a significant time savings. Therefore, many students prefer blended courses over the face-to- 
face ones due to the reduction in time and space commitment (Strambi \& Bouvet, 2003; Wingard, 2004; McCray, 2000).

Studies on flipped classrooms have yielded mixed results. Some previous studies found that the flipped classroom has a positive impact on student learning and educational experience. For example, Baepler et al. (2014) found that students' learning outcome is significantly better in a flipped classroom than that in a regular face-to-face classroom. However, other researchers argue that no evidence is found that flipped learning has improved students' grades and indicated that there was no significant difference in student performance between flipped classrooms and traditional classrooms (Kim et al., 2014; Davies et al., 2013; Strayer, 2012). Despite the mixed empirical results, indirect evidence such as student self-reported data shows that students preferred the flipped method compared with traditional pedagogical strategies (Roach, 2014; Gilboy et al., 2016).

\subsection{Student Engagement and Active Learning}

Student engagement is a key to the success of flipped classrooms, especially during the inclass time. Learning can be deepened, enhanced, and become meaningful if students are actively engaged through interactivity, multiple roles and social engagement such as group work and discussions. Researchers found that learning increases as the amount of student engagement increases (Grissom et al., 2003; Carini et al., 2006). National Center for Education Statistics (2016) further reported that student engagement can also positively impact learners' persistence and lead to learners being more likely to complete their undergraduate degree.

Active learning, a pedagogical model, has been shown to be effective in strengthening student engagement and making students responsible for their own learning (Gatch, 2010). Active learning was first defined by Bonwell and Eison (1991) as "anything that involves students in doing things and thinking about the things they are doing". This pedagogical approach actively engages students in the learning process and helps students move from remembering and understanding to analyzing and creating in Bloom's Taxonomy level of learning. It refers to a broad range of teaching strategies that engage students. In a face-toface classroom setting, these strategies often involve activities with some amount of collaborative group work that facilitate knowledge exchange, construction, and transfer. Thus, the instructor is able to spend significantly more time with the students who are engaged in active learning compared to the student-as-passive vessel context (Gannod et al., 2008; Felder \& Brent, 2009).

\subsection{Active Learning Space}

While faculty are adopting active learning teaching strategies and working towards maximizing student engagement, traditional classroom spaces designed for students as 
passive knowledge receivers from a lecturing professor at the front of the classroom present many challenges. These spaces cannot be easily configured to support collaborative group work as well as instructor mobility and participation in students' learning. Researchers and practitioners have called for the design of new active learning environment to support collaborative and project based learning (Jamieson, 2003; Harris, 2010; Harvey \& Kenyon, 2013). These new active learning spaces often include modular and flexible furniture that can be easily rearranged to accommodate teaching and learning. New technologies have also been integrated to support collaborative learning activities. Researchers have reported that active learning spaces have positive impact on student engagement and student expectations (Webb et al., 2008).

\section{Background}

This study is held at a regional comprehensive state university, which is located on the east coast of the United States near a major metropolitan area. Currently, there are about 17,500 students enrolled in the university, including both undergraduates and graduates. The university has been encouraging faculty to adopt flipped classroom strategies to utilize class time more efficiently and promote active learning. During the last three years, the university has constructed fifteen new active learning classrooms in three major academic buildings. By integrating the flipped classroom pedagogy with active learning spaces, the researchers hope to provide a flexible, collaborative, and effective way to support students' learning.

A general business education course was selected for this study. The demand for this course has been trending upwards within the last few years. The department offers around 15 sections on average every semester. Students are from different majors with different learning styles and pathways.

Our research questions is: Integrating with active learning space, does flipped classroom yield effective student learning outcomes and student engagement as compared to face-toface classroom?

\section{Methodology}

Two sections of the business course that taught by the same instructor during one semester were selected for our study. The two sections had the exact same coverage and evaluation policy while one was a flipped class and the other was a face-to-face class. Additionally, the flipped class was held in a newly renovated active learning classroom. Students were evaluated based on class participation, homework and exams. We examine students' performance from the two sections. To determine whether there is a significant difference 
between the two sections, we use the t-test. The p-value is reported in the result table. We also designed a survey to assess students' perception of the learning environment and outcome. Six-point Likert scale was used to measure the responses, with 6 being "strongly agree" and 1 being "strongly disagree". The survey was administered at the end of the semester before the final exam.

\section{Results and Discussion}

The sample included 36 students in the face-to-face class and 37 students in the flipped class. Both of the two sections were consist of business major and non-business major students. Table 1 presents the composition of the two classes.

Table 1. Class composition of the two sections

\begin{tabular}{lcc}
\hline & Face-to-face Class & Flipped Class \\
\hline Business Major & 26 & 30 \\
No-Business Major & 10 & 7 \\
\hline
\end{tabular}

As shown in Table 1, the majority of the students were business majors in both classes. Business majors include accounting, economics, finance, management and marketing. Nonbusiness majors are students from colleges other than the business school. There were 26 business major students and 10 non-business major students in the face-to-face class, while 30 business major students and 7 non-business major students in the flipped class. In general, there is no significant difference regarding student composition between the two classes.

In the face-to-face class, students were required to present in every class and the instructor provided in-class lectures. In the flipped class, students were required to watch lecture videos that instructor prepared in advance and then brought questions to the class. The instructor used the class time to answer questions and clarify students' confusion. In addition, the instructor designed exercise problems and hands-on activities utilizing active learning spaces to deepen students' understanding of the course materials.

\subsection{Quantitative Results and Discussion}

Table 2 shows the average score of the three in-class exams and the final grade for the course between the face-to-face and flipped class. T-statistics is used to test if there is significant difference of student performance between the two classes. 
Table 2. Student's performance between the face-to-face and flipped class

\begin{tabular}{lcccccccc}
\hline & \multicolumn{2}{c}{ Exam \#1 } & \multicolumn{2}{c}{ Exam \#2 } & \multicolumn{2}{c}{ Exam \#3 } & \multicolumn{2}{c}{ Final Grade } \\
\hline & $\begin{array}{l}\text { Face-to- } \\
\text { face }\end{array}$ & Flipped & $\begin{array}{c}\text { Face-to- } \\
\text { face }\end{array}$ & Flipped & $\begin{array}{c}\text { Face-to- } \\
\text { face }\end{array}$ & Flipped & $\begin{array}{c}\text { Face-to- } \\
\text { face }\end{array}$ & Flipped \\
\hline Observation & 36 & 37 & 35 & 36 & 35 & 36 & 36 & 37 \\
Mean & 84.6 & 83.2 & 82.1 & 77.3 & 73.3 & 74.1 & 81.2 & 81.1 \\
T-statistics & 0.598 & & 1.488 & -0.332 & 0.039 \\
P-value & 0.552 & & 0.141 & 0.741 & 0.969 \\
\hline
\end{tabular}

The mean score of the Exam \#1 is slightly higher in the face-to-face class. Exam \#1 only covered introductory concepts and principles for the course. The materials were relatively easy to understand. Students performance were very comparable between the two classes. The contents tested in the Exam \#2 were related to comprehensive understanding of economic indicators and models. It required the mathematical and graphical skills. The mean score of the Exam \#2 in the face-to-face class was 82, which is about 5 points higher than the mean score in the flipped class. Exam \#3 was built on the knowledge learned from the previous two exams and developed further to analyze policy implications. The mean score in the flipped class becomes a little higher in the Exam \#3. When combining other evaluation components, the mean score of the final grade is almost same between the two classes. Using the t-test, there is no evidence of statistically significant difference between the two classes for all the exam scores and final grade. This result is consistent with other flipped classroom research findings that flipped and traditional classrooms yielded no significant difference on student performance (Kim et al., 2014; Davies et al., 2013).

Additionally, we do see a learning curve for students to adapt the flipped classroom format. When the course material involved equations and graphs which were not taught by the traditional face-to-face format, students might need extra time to adjust the learning process. It explained why the mean score of the Exam \#2 was lower for the flipped class than that of the face-to-face class. After the learning curve, students were able to take advantage of the flipped class more effectively which was evidenced by the higher mean score in the Exam \#3 comparing with the face-to-face class.

A brief survey was developed to assess students' learning experience. The response rate was $89 \%$. Table 3 reports the mean score of the responses to each question. A score of 6 indicates "strongly agree" and a score of 1 indicates "strongly disagree". 


\begin{tabular}{llcc}
\hline & & $\begin{array}{c}\text { Face-to- } \\
\text { face }\end{array}$ & Flipped \\
\hline $1 \quad$ The overall quality of teaching. & 5.0 & 5.1 \\
$2 \quad \begin{array}{l}\text { The classroom interactions (instructor to student, student to student) } \\
\text { are positive. }\end{array}$ & 5.7 & 5.8 \\
3 & $\begin{array}{l}\text { The classroom environment was comfortable and promoted } \\
\text { learning. }\end{array}$ & 5.3 & 5.6 \\
$4 \quad \begin{array}{l}\text { The instructor maintained a positive classroom atmosphere. } \\
5\end{array}$ & 5.6 & 5.2 \\
$\quad \begin{array}{l}\text { The class activities are organized in a way that helped student learn } \\
\text { the material. }\end{array}$ & 5.1 & 5.7 \\
& $\begin{array}{l}\text { The instructor explained concepts using real-world examples, } \\
\text { analogies, or circumstances relevant to student's life. }\end{array}$ & & 5.5 \\
\hline
\end{tabular}

The survey results show that students in the flipped class rated every question higher than the students in the face-to-face class. In general, they agreed flipped class provided more positive learning experience. The active learning space also facilitated the learning process with a comfortable and engaging environment.

\subsection{Qualitative Results and Discussion}

The final question of the survey elicited participant comments. The following themes were identified among student comments: Class Video, Class Organization and Activities, and Learning Environment. We will describe each theme with examples of relevant comments provided.

Class video is the most frequently referenced theme. The videos referred here are the prerecorded lecture videos for students to watch at home. Students watch these videos in the learning management system during the "online" portion of the course. All comments about class videos are positive. One student commented: "I enjoyed being able to watch class videos because it allowed me to learn the content at my own pace." Some sang high praises of video lectures: "I excelled and enjoyed watching the online lecture....", "...having the lectures online is extremely helpful".

Class organization and activities are overlapping themes that often mentioned together. This is because the way class activities run has a huge impact on class organization, especially in a flipped classroom. Multiple students commented that being able to watch the 
videos online and participate in more meaningful activities in class helped them learn better: "...class time is used to review and do activities that make sure we understand", "I really liked the hybrid format of the course...come to class to reinforce that material through activities."

The Learning environment theme refers to the active learning classroom space. This space encompasses a group of elements such as flexible furniture, multi-screen projection system, collaborative work space, etc. Two students offered specific, positive comments toward the class space. One student commented: “...very friendly, created a comfortable learning environment". The other student felt the same way: “... I also really liked how structured it (the classroom) was... which helps me learn better."

\section{Conclusion}

The flipped classroom model offers a new approach to instruction that allows teachers to foster active and collaborative learning as well as provide flexibility to anytime and anywhere learning. Findings from this study suggest that flipped classroom utilizing active learning spaces is as effective as traditional face-to-face instruction. Furthermore, students have a more positive learning experience in the flipped classroom setting for both online and face-to-face components. The use of active learning spaces also contributes positively to building a comfortable and engaging learning environment.

No study is without its limitations and ours is no exception. The sample size was relatively small and there was only one instructor involved in the study. There is also the novelty effect of the new classroom, which may diminish overtime. Continuing research is needed to involve larger sample sizes, more instructors, as well as more in-depth and specific student feedback and collect longitudinal data.

\section{References}

Baepler, P., Walker, J. D., \& Driessen, M. (2014). It's Not About Seat Time: Blending, Flipping, and Efficiency in Active Learning Classroom. Computers \& Education, 78, 227-236.

Bonwell, C. C., \& Eison, J. A. (1991). Active learning: Creating excitement in the classroom (ASHE-ERIC Higher Education Rep. No. 1). Washington, DC: The George Washington University, School of Education and Human Development.

Carini, R. M., Kuh, G. D., and Klein, S. P. (2006). Student engagement and student learning; Testing the linkages. Research in HigherEducation, 47(1), 1-32.

Carroll-Barefield, A., \& Murdoch, C. (2004). Using Online Learning to Enhance Interdisciplinary Education. Journal of Allied Health. 33(1), 78-81.

Davies, R. S., Dean, D. L., \& Ball, N. (2013). Flipping the Classroom and Instructional 
Technology Integration in A College-level Information System Spreadsheet Course. Educational Technology Research and Development. 61(4), 563-580.

Felder, R.M. \& Brent, R. (2009). Active learning: An introduction. American Society for Quality Higher Education Brief, 2(4), 1-5.

Gannod, G., Burge, J., \& Helmick, M. (2008). Using the inverted classroom to teach software engineering, Leipzig, Germany.

Gatch, D. (2010). Restructuring introductory physics by adapting an active learning studio model. International Journal for the Scholarship of Teaching and Learning, 4(2).

Gilboy, M. B., Heinerichs, S., \& Pazzaglia, G. (2015). Enhancing Student Engagement Using the Flipped Classroom. Journal of Nutrition Education and Behavior. 47(1), 109114.

Grissom, S., McNally, M. F., \& Naps, T. (2003). Algorithm visualization in CS education: comparing levels of student engagement. Paper presented at the Proceedings of the 2003 ACM symposium on Software visualization, San Diego, California.

Harris, S. (2010). The Place of Virtual, Pedagogic and Physical Space in the $21^{\text {st }}$ Centuary Classroom. EDULEARN $2^{\text {nd }}$ International Conference on Education and New Learning Technologies, Barcelona, Spain.

Harvey, Eugene J. and Kenyon, Melaine C. (2013). "Classroom Seating Considerations for $21^{\text {st }}$ Century Students and Faculty." Journal of Learning Spaces, 2(1).

Jamieson, P. (2003). Design more effective on-campus teaching and learning spaces: a role for academic developers. International Journal for Academic Development, 8(1/2), 221236.

Kim. M. K., Kim, S. M., Khera, O., \& Getman, J. (2014). The Experience of Three Flipped Classrooms in An Urban University: An Exploration of Design Principles. The Internet and Higher Education. 22, 37-50.

McCray, G. E. (2000). The Hybrid Course: Merging On-line Instruction and The Traditional Classroom. Information Technology and Management. 1(4), 307-327.

Means, B., Toyama, Y., Murphy, R., \& Baki, M. Jones, K. (2010). Evaluation of EvidenceBased Practices in Online Learning: A Meta-Analysis and Review of Online Learning Studies. US Department of Education.

National Center for Education Statistics (2016). The Condition of Education 2016. NCES 2016-144

Roach, T. (2014). Student Perceptions Toward Flipped Learning: New Methods to Increase Interaction and Active Learning in Economics. International Review of Economics Education. 17, 74-84.

Seaman, J.E., Allen, I.E., \& Seaman, J. (2018) Grade Increase: Tracking Distance Education in the United States. Wellesley MA: The Babson Survey Research Group.

Shea, P. (2007). Bridges and Barriers to Teaching Online College Courses: A Study of Experienced Online Faculty in Thirty-six Colleges. Journal of Asynchronous Learning Networks. 11(2), 73-128. 
Strambi, A. \& Bouvet, E. (2003). Flexibility and Interaction at a distance: A Mixed-mode Environment for Language Learning. Language, Learning \& Technology. 7(3), 81-102.

Strayer, J. F. (2012). How Learning in An Inverted Classroom Influences Cooperation, Innovation and Task Orientation. Learning Environments Research. 15(2), 171- 193.

Webb, K. M., Schaller, M. A., \& Hunley, S. A. (2008). Measuring library space use and preferences: Charting a path toward increased engagement. portal: Libraries and the Academy, 8(4), 407-422.

Wingard, R. (2004). Classroom Teaching Changes in Web- Enhanced Courses: A MultiInstitutional Study. Educause Quarterly. 27(1), 26-35. 